\title{
Irish Studies in Cyprus
}

\author{
Paul Stewart \\ University of Nicosia, Cyprus
}

Copyright (c) 2019 Paul Stewart. This text may be archived and redistributed both in electronic form and in hard copy, provided that the author and journal are properly cited and no fee is charged for access.

\begin{abstract}
This paper assesses the current state of Irish Studies in Cyprus and looks forward to possible ways this might be improved. The historical parallels between the islands of Ireland and Cyprus suggest a fertile ground for possible cultural exchanges, but it is argued that the educational and social conditions in Cyprus mitigate against this to a great degree. The issue of Ireland acting as a post-colonial paradigm for locations such as Cyprus - itself a former British Colony - is central to an understanding of the problems and possibilities facing the wider dissemination of Irish culture and literature beyond the currently recognised centres of Irish Studies within Europe.
\end{abstract}

Key Words. Irish Studies, Irish Literature, Cyprus, Tertiary Education, Post-Colonial Studies.

Resumen. En este trabajo se analiza el estado actual de los estudios irlandeses en Chipre y se avanzan posibles vías para que la situación actual pueda mejorarse. Los paralelismos históricos entre las islas de Irlanda y de Chipre sugieren que puede existir un terreno en el que se produzcan fructíferos intercambios culturales, aunde las condiciones de la educación y de la sociedad en Chipre actúan en gran medida contra este objetivo. La concepción de Irlanda como paradigma poscolonial para lugares como Chipre - también una antigua colonia británica - es de importancia capital para entender los problemas que pueden encontrarse al intentar extender la cultura y la literatura irlandesas fuera de los centros ampliamente reconocidos de los estudios irlandeses dentro de Europa.

Palabras clave. Estudios irlandeses, literatura irlandesa, Chipre, educación universitaria, estudios poscoloniales.

\section{Ireland and Cyprus: Parallels and Differences}

After years of colonial domination by Britain, the island is partitioned. Approximately twothirds of the island is under the administration of the Republic, whilst the remaining third is under the sway of another country.

The basic facts of Cyprus are, therefore, not dissimilar to those pertaining in the island of Ireland. Cyprus gained independence from Britain in 1960, after almost a decade of 
political turmoil, including the violent campaign for self-determination conducted by EOKA (Ethniki Organosis Kyprion Agoniston) against British military and administrative targets. The security of the new republic under the presidency of Archbishop Makarios III was shortlived, and, by 1964, tensions and violence between the Turkish-Cypriot and Greek-Cypriot communities led to a deployment of UN peace-keepers and the segregation of certain areas along ethnic/religious lines. As a right-wing Junta took control in Greece, a re-iteration of EOKA, now known as EOKA-B, began a violent campaign against President Makarios in the hopes of securing enosis - union with Greece. The EOKA-B coup of 1974 in turn led to Turkish military intervention in that same year and to the de facto partition of the island that still pertains today. Britain retains large parts of the island in the shape of military bases that were guaranteed under the terms of independence.

If one were to strip this deeply complicated and long-lasting situation - the language of which is fraught with difficulties - into its basic elements, the Irish parallels are striking: colonial rule; independence struggle; ethnic/religious conflict; the role of the Church; postindependence conflict; partition. Indeed, there are other ways in which the Irish and Cypriot experience might be seen to run in parallel, not least in the history of emigration and the creation of diasporas in Britain, Australia, America and elsewhere.

Yet one should also notice the lack of contact between Cyprus and Ireland until relatively recently. This is hardly surprising given that the two islands mark the Eastern and Western extremes of Europe, as geographically and politically defined. This is compounded by crucial cultural differences, with Cyprus still bearing many of the traces of Ottoman rule and influences from its very close Levantine neighbours. In the case of those identifying as Greek-Cypriots, one should also not underestimate the cultural influence of the Eastern Orthodox church; a church markedly different in many ways to those of the Western tradition. The same might also be noted in the role of Islam amongst those identifying as TurkishCypriot, albeit with the caveat that many Turkish-Cypriots maintain a relatively secular outlook.

Since joining the European Union in 2004, Cyprus has opened itself up to greater contacts with its European fellow nations, and Ireland is no exception. Yet one might wonder as to the nature of those contacts. Currently, after the recent collapse of the airline Cobalt, there is no direct, scheduled flight from Cyprus to Ireland. There are very few Irish business concerns in Cyprus, and few immigrants to the island, with as few as 1,500 registered with the Irish Embassy. The main point of contact is tourism, with thousands of visitors to Cyprus annually (the Irish Embassy is currently attempting to collate exact numbers). It should be pointed out, though, that such tourism is focused in the main coastal resorts.

\section{The Structure of Higher Education in Cyprus and the Practice of Irish Studies}

If the possibilities of Irish Studies are to be properly assessed, then the infrastructure and culture of Higher Education in Cyprus needs to be understood.

In many ways, and certainly compared to Ireland, the university system in Cyprus is still very much in its infancy. The first university in the republic, the state-sponsored University of Cyprus, was established in 1989 and opened to its first students in 1992. The language of instruction was chosen as Greek (although this was much debated at the time), with the exception of foreign languages and literatures.

Prior to the inauguration of the University of Cyprus, students had to pursue their studies abroad, with Britain and the USA the most popular choices, although many also studied in countries of the former Soviet Union and Warsaw Pact (Cyprus was officially part of the non-aligned movement during the heights of the Cold War but AKEL, the Communist Party, forged many links with countries within the domain of Soviet influence). Obviously, 
this severely restricted the type of person who could access Higher Education; an issue addressed by the University of Cyprus being free to local students.

Given the limited number of spaces available at the University of Cyprus, a host of privately owned further education colleges sprang up in the subsequent years. Many of these gained University status with a change in the law in 2005. These colleges - in which the language of instruction was primarily English - initially focused on vocational courses but their change of status also saw a change in the types of course being offered with a growth in arts, humanities and social sciences. Currently, there are four major private universities: University of Nicosia (formerly Intercollege), The European University Cyprus (formerly Cyprus College), Frederick University (formerly Frederick Technical College) and Pafos University. Of these, only The University of Nicosia and The European University Cyprus have a strong humanities and arts portfolio.

Beyond the academic control of the government of the Republic of Cyprus, the higher education system in the North of the country is very different. There are a multitude of higher education institutions, which often operate as feeder colleges, but there is little or no teaching of non-Turkish literature or cultures.

On paper, then, only three institutions - The European University Cyprus, The University of Nicosia, and The University of Cyprus - offer courses or programmes in which Irish studies might be a possibility. All three offer English Language and Literature undergraduate courses and it is under such an umbrella that cultural products of Ireland might be contained, at least as these institutions are currently configured. However, one should note that these institutions operate under a number of restrictions. The private Universities are constantly under pressure to justify programmes in terms of student numbers alone, leading the European University Cyprus to recently suspend admissions for its face-to-face English Language and Literature undergraduate degree, although it has continued this programme online. Both private and public universities operate what are in effect dual-subject programmes in language and literature, which obviously restricts the proportion of courses devoted to literature and limits the scope of focusing on Irish Literature, let alone other aspects of Irish studies.

The relative youth of the University system can also be seen in the research interests and educational backgrounds of current faculty. The vast majority of current faculty had to gain their doctorates outside of Cyprus, with the UK and USA, as well as Greece, being the most popular. No full-time faculty member of the above universities has studied in Ireland. The geographical dispersal of faculty during their $\mathrm{PhD}$ years is also reflected in their own areas of specialisation, which range from the Beats, to Native American literature, Early Modern Drama, post-structuralist theory, post-colonialism (mainly concerning the Caribbean, India and Cyprus itself), amongst others. As primarily a Beckett scholar, I come closest to working within Irish Studies, but I would not identify myself as an Irish Studies scholar. Rather, I am a Beckett scholar who draws on Irish Studies.

The small number of full-time faculty together with the wide-range of research interests has meant that the pursuit of any common academic area has so far proved elusive. Cyprus does have a chapter of the European Society for the Study of English (ESSE), but this has not yet provided a sense of purpose. Discussion within the group as to how our disparate efforts might be brought together are still in the early stages and are focused on the possibilities of shared thematic issues such as migration and transnationalism, language and identity. 


\section{A Case in a Thousand: Teaching Joyce in Cyprus}

In order to uncover some of the impediments to understanding Irish literature and culture amongst Cypriot undergraduates, I offer the following case study of my teaching James Joyce's "Araby" and A Portrait of the Artist as a Young Man. For many years I have chosen "Araby" as an almost model exemplar of the possibilities of the short story as part of an Introduction to Fiction course. Portrait was taught in a now defunct course focusing on Modernist and Post-modernist novels. As with so much teaching of Irish Literature at the moment in Cyprus, neither text was taught as part of a broader Irish context, but as part of cross-cultural, formal movements and developments within literature in the case of Portrait and, in the case of "Araby," as part of the training of interpretative skills which also draws on a wide range of texts from different traditions within English, encompassing American, Caribbean, Indian texts and others. This latter point is worth emphasising: Irish literature in English operates within a world of competing Englishes to which one wishes to expose the student. To what degree, and in what way, Irish literature can provide a unique selling point within this competitive arena shall be focused on later.

The student encounters "Araby" through an introductory anthology (the precise textbooks have changed over the years - from the Norton to the Longman to the McGraw Hill and other anthologies - but the majority of the actual stories in those books is remarkably stable) which provides some biographical information and an occasional footnote; there is little or no historical or cultural context provided. The presentation of "Araby" in such a way already mitigates against the student appreciating the particular Irishness (in whatever sense one would wish to emphasise it) of the story and its author.

I have found myself addressing this lack in two particular areas: the religious and the historico-political. The Catholic imagery and language which permeate the story and upon which the crucial blurring of the sacred, secular and sexual within the text depends, are not easily recognised by those brought up within Eastern Orthodoxy in which the iconography of the Virgin Mary, for example, or the rituals of communion, are markedly different. With regard to the historico-political context, the broad outlines of the situation of preindependence Ireland are very little known, but the nature of colonial rule and the stagnation of the colonised culture can be made readily appreciated with reference to parallels within Cyprus. So, the specifics of O'Donovan Rossa might need to be uncovered, but the concept of fighting against Imperial rule is one with which the student is familiar.

These two issues are even more apparent, however, when teaching A Portrait of the Artist. To someone of a Protestant English background such as myself, the rituals and the influence of the church in Ireland might not be instinctively appreciated, but at least there is a sense of a common, albeit divergent tradition wherein the Jesuits, Augustine, Aquinas, Scholasticism and so on are reasonably familiar. The Eastern Orthodox church does not share in this tradition and one cannot assume that the students have a fair working knowledge of the Bible as, once again, there is a very different relationship between the individual and the book within the Eastern tradition. In this regard, Timothy Ware makes a fine distinction regarding the role of the Bible within Orthodoxy. He is surely right to argue that "the Christian Church is a Scriptural Church: Orthodoxy believes this just as firmly, if not more firmly, than Protestantism" but how one encounters the Bible is subtly different for "it must not be regarded as something set up over the Church, but as something that lives and is understood within the Church" (199). In practical terms, this refers to the frequent recitation of scripture within the Church itself and much less to the private contemplation of the text, leading Ware to admit that "Orthodox scholars have not been prominent" in the field of "critical and historical study of the Bible" (201). 
Despite these difficulties, some students - somewhat more than a case in a thousand connect with the world of Joyce, and, by extension, other Irish cultural products. Yet it is important to note that there are such difficulties and that they are particular, either in degree or kind, to students of Greek-Cypriot heritage. In short, an awareness of the specifics of an Ireland - Cyprus cultural intersection is necessary.

\section{Ireland as a Post-Colonial Paradigm}

The notion that Ireland can act as a post-colonial paradigm for approaching other cultures is one which is popular, although debatable. As Eoin Flannery has argued, the "depth and protraction of Ireland's colonial experience, together with the vanguard initiative of its anticolonial agitation, are judged as both instrumental to and informative of subsequent Third World anticolonial movements" (19), to which one might wish to add Cyprus, albeit not a Third World country as such. Terry Eagleton similarly recognises such possibilities, arguing that Irish studies revolves around "[o]n the one hand roots, belonging, tradition, Gemeinschaft, and on the other, again with marvelous convenience, exile, diffusion, globality, diaspora ... Irishness thus becomes a terrain on which some of the most typical, worldhistorical issues of our day can be seen to congregate" (Eagleton 11-12). However, in this "marvelous convenience" one might detect a hint of scepticism on Eagleton's part, and the possible danger that because Ireland can be used to address so many issues its exemplary force might be weakened by diffusion. In contrast, and in the context of Irish studies within German speaking countries, Jochen Achilles notes that "Irish culture, precisely because its struggle for independence precedes nations and regions outside Europe, is considered not a model but an exception in the postcolonial context" (18). This anomalous position is one that David Lloyd embraced. The terms in which he describes Ireland might, with a certain finessing, apply equally to Cyprus:

A culture which is geographically of Western Europe though marginal to it and historically of the decolonizing world, increasingly assimilated to that Europe, while in part still subject to a dissimulated colonialism ... With peculiar intensity, Irish culture plays out the anomalous state of a population whose most typical experience may be that of occupying multiple locations, literally and figuratively. (2-3)

Arguably, the anomalous state of Ireland is precisely what makes it attractive as a postcolonial paradigm within a Cypriot context. Both countries certainly experienced a protracted period of colonial rule, and both experienced rule by a fellow European country. Similarly, both countries have had to find their way within a European context since independence. However, such similarities should not shield us from important differences. Firstly, Cyprus was under the control of Britain for a relatively short time. Britain first acquired Cyprus in 1878 as a Protectorate in accordance with an agreement to support the Ottoman Empire as part of the Berlin Treaty of the same year. Britain nominally "leased" the island from the Sultan, but in effect any excess moneys generated from the island were held by the Bank of England against Crimean War debts upon which the Ottoman Empire had defaulted. Britain only came into full possession of the island at the outbreak of World War I, and Cyprus did not become a Crown Colony until 1925. The protracted nature of colonisation of Cyprus is more accurately reflected by Venetian and then Ottoman rule, from 1489-1571 and 15711878, respectively. Upon gaining independence in 1960, Cyprus therefore ended 470 years without self-determination.

These dates highlight that Britain came into possession of Cyprus when it was losing its grip on its oldest of colonies, Ireland. Cyprus had no institutions or levels of development 
comparable to Ireland. Indeed, the capital, Nicosia, did not exceed the limits of its Venetian walls when Britain first acquired it. With its population of Greek-Cypriot, Turkish-Cypriot, and significant minorities of Armenians and Latins, not to mention the infrastructure and cultural practices of Ottoman rule, the question of how European Cyprus was at the time was very debatable. Many of the officials despatched to take control of the island certainly displayed attitudes which betray a view of the locals as less than European. Hugh Montgomerie Sinclair, one of the officers in charge of supervising the landing in 1878, made little distinction between Greek- and Turkish-Cypriot workers and the punishments meted out to them:

The men, some half dozen, were brought up in full sight of the whole gang. I asked the first, a great stalwart peasant with a fierce moustache and truculent air, if he would go on working. "Ochi"(no) he replied. I suddenly seized him by the collar, bent him down with all my strength and administered cuts with my cane on the softest part of his person till he roared out that he would work. I called up the second, a hulking Mohammedan, with my cane at the "carry". He would not reply, so again I administered personal chastisement, till he, too, gave in. The others needed no coercion and the victory was won. (Sinclair 70)

In many ways, therefore, perhaps the earlier experiences of colonialism within Ireland, such as the rise of plantations, the myth of the Irish Wildman and the characterisation of Ireland as an at once barbaric and romantic wilderness, might offer ways of exploring parallels with Cyprus.

One should not assume, then, that the experience of colonial rule, even with such close parallels as exist between Cyprus and Ireland, can form the platform upon which a cultural exchange can be based without first taking into account significant cultural differences. Joyce is again instructive in this context. Students at an undergraduate level can readily appreciate the experience of colonial rule and make the necessary adjustments to consider the Irish and Cypriot experience alongside each other. Where there is more resistance is in Joyce's insistence that Ireland is twice occupied, by Britain and by the Catholic Church, as Stephen later puts it in Ulysses: "I am the servant of two masters ... an English and an Italian" (24). The latter half of this equation does not gain the same traction amongst students who identify as Eastern Orthodox, even if their adherence to the church is in name only. This might be attributed to the continuing influence of the Church which also offered a rallying point for Greek-Cypriot identity under successive non-Orthodox regimes, be it by the Lusignans, Venetian, Ottoman or British rule.

There are of course a plethora of other literatures in English that can furnish Cyprus with insights into its own colonial and post-colonial state and, by and large, these have been more widely embraced as possible models. The "World Literature" course at The University of Nicosia, for example, focuses on texts drawn from the Caribbean, India, Canada and South Africa, whilst omitting Ireland entirely, although a section of the textbook anthology is devoted to it (Baldwin and Quinn). A further case in point is the collection of essays Vernacular Worlds, Cosmopolitan Imagination, edited by Stephanos Stephanides (University of Cyprus) and Stavros Karayanni (European University Cyprus), which arose out a conference held in Nicosia of ACLALS - the Association for Commonwealth Literature and Language Studies. As the title of the volume implies, this was a study devoted to postcolonial literature but, because it was published under the aegis of ACLAS, it was a study that would not necessarily focus on Irish postcolonial paradigms, although my own work on Beckett and Coetzee was included. The volume was intended to assess and question "the political and ethical ways of renegotiating the tensions between incorporation and dispersion in the re- 
formation of what we may call World Literature" (xii), and certainly Irish culture could have much to contribute to such an endeavour. One of the core concerns of the volume was to address issues of the centre and the peripheral; a concern that has indeed been identified as one of the areas in which Irish Studies can perform a key role, as Cronin and Izarra attest (Mahony et al. 25). However, it is important to recognise the meta-textual infrastructure that supported such a publication. As the editors rightly acknowledge, ACLALS and the Commonwealth Foundation provided some funds towards the publication of the work. Cyprus not only belongs to the European Union but also to the Commonwealth, which Ireland left upon becoming a Republic. In effect, it has a choice of alignments and, given the funding available under the Commonwealth and the long-established Association for Commonwealth Literature and Language Studies, Cyprus might feel more at home within such a grouping at the moment.

Despite all the caveats that I have elaborated so far, Irish literature is commonly taught within tertiary education within the Republic. Yet to what degree literature from Irish writers is taught as a specifically Irish phenomenon is open to doubt. A straw poll amongst lecturers of the three Universities reveals a list of authors taught that is far from surprising: Wilde, Yeats, Joyce, Beckett, Heaney. This male-centred list is undoubtedly secure in its canonicity and therein lies a problem; these authors are taught as exemplary within contexts which do not necessarily connect them with Irish cultural mores. So, as Olga Michael, adjunct lecturer at the University of Cyprus, bears witness, Wilde is taught within the contexts of gay literature and aestheticism. Beckett is taught within the context of modern drama and his impact on the dramaturgy of the twentieth century is the key area of pedagogical concern. Joyce - from the exemplary short stories of Dubliners to the modernism of Ulysses - is most commonly approached as making key formal contributions to Western literature, and the same could be said for Yeats in this regard. Stephanos Stephanides of the University of Cyprus sums up his own approach, stating that "I would provide relevant cultural and historical information but the focus was on genre not Irish Studies".

In effect then, the Irish specifics of a text or author are taught in order to teach broader aims, mainly concerning the generic developments of literature in English. Joyce is more a modernist than he is an Irishman; Beckett more a re-inventor of theatre internationally than a writer with important links to the nation of Ireland. Given the restrictions of teaching literature at University level as mentioned above, this should not be a surprise but it provides an important corrective: one should not assume that the teaching of authors from Ireland amounts to teaching Irish literature as such.

The focus of this chapter has almost entirely been on literature. This is no accident. There is no evidence to suggest that other Irish cultural forms are taught within Universities or form a part of Cypriot consciousness concerning Ireland. This situation is one that might well be recognised by other non-Anglophone countries, in which "literature occupies a prominent, even dominant, position, with Joyce, Yeats, Beckett, the Irish Literary Revival and contemporary Northern Irish poetry" forming a canon in the classroom (Mahony et. al 1).

\section{Prospects}

The picture that has thus far been painted is no doubt a gloomy one in terms of Irish Studies. With a small cohort of faculty pursuing a variety of research interests, students who find much about Ireland quite alien, and important cultural and political differences, Irish studies is fighting an up-hill battle, despite the possibly fruitful parallels between the two islands.

Yet change might already be underway in the shape of the Erasmus schemes for both students and faculty. In recent years, both The University of Cyprus and The University of Nicosia have welcomed students from the Republic of Ireland and this has led to heightened 
authenticity in the classroom when approaching works of Irish literature, although I must add that there does seem to be a resistance on the part of some students to those very authors Yeats, Joyce, Beckett, Heaney - that form the mainstay of current teaching. This might be seen as a challenge to reimagine what elements of Irish studies can be addressed. If faculty members were to embrace more contemporary cultural products then perhaps a greater degree of cultural exchange and affiliation might occur. There will no doubt be difficult decisions to make in this regard. The sense of necessity that attaches to teaching an "established" canon within a restricted curriculum is a strong one. This might seem inevitable, but it is no less unfortunate. As Harte and Whelan have argued, "Irish Studies heuristic should upset the order of things, should destabilise canons and disturb established categories of knowledge" (4), but such disruptive possibilities are currently under-explored.

As Erasmus is a reciprocal arrangement, Cyprus-based students can spend a semester or more studying in Ireland. Erasmus + offers Cyprus-based academics the chance to teach for limited amounts of time in universities within Ireland, and vice versa. Again, there is an element of competition in these cases as universities have multiple Erasmus partners, and the draw of other more traditional destinations can be a powerful one. Nevertheless, Erasmus is certainly an avenue for exchange, creating networks and just enjoying a day-to-day exposure to Ireland and Irish culture which may feed back into the appreciation of Ireland within Cyprus.

David Lloyd's description of a "population whose most typical experience may be that of occupying multiple locations, literally and figuratively" might offer a way forward, if not in creating an Irish Studies hub within Cyprus, then at least in creating an arena in which Irish Studies can form an important part. Cypriot literature since 1974 has been marked by just such a shifting multiplicity of locations, identities and affiliations as Lloyd describes. The output of Turkish- and Greek-Cypriot writers, both on the island and as part of the diaspora, not to mention writers from minorities such as the Armenians, frequently highlights a sense of dislocation and of competing claims to identity. Mehmet Yashin, for example, writes that "Where you were born, where you died, these no longer matter / for now you are elsewhere" ("Someone Else's Father") and Stephanos Stephanides evokes a sense of in-betweenness: "Lamenting a lack but daring to hope / Between a mountain too stolid / And a sea too restless" ("Octobriana"). This uncanny dislocation is one that Irish Studies has addressed, and one that offers the possibility of a Cyprus/Ireland exchange in a broader European context of such shifting, multiple identities.

\section{Works Cited}

Achilles, Jochen. "How to Strengthen Irish Studies throughout Europe? A Diagnosis Based on the German Speaking Countries". Estudios Irlandeses: Journal of Irish Studies 13 (2018): 14-26.

Baldwin, Dean and Patrick J. Quinn. An Anthology of Colonial and Postcolonial Short Fiction. Andover: Cengage, 2006.

Eagleton, Terry. "The Ideology of Irish Studies". Bullán: An Irish Studies Journal 3.1 (1997): 5-14.

Flannery, Eoin. Ireland and Postcolonial Studies: Theory, Discourse, Utopia. Basingstoke: Palgrave, 2009.

Harte, Liam and Yvonne Whelan. Ireland Beyond Boundaries: Mapping Irish Studies in the Twenty-First Century. Dublin: Pluto Press, 2007.

Joyce, James. Ulysses. Harmondsworth: Penguin, 1992 (1922).

Lloyd, David. Anomalous States: Irish Writing and the Post-Colonial Moment. Durham: Duke University Press, 1993. 
Mahony, Christina Hunt, Laura Izarra, et.al., eds. The Future of Irish Studies: Report of the Irish Forum. Prague: Centre for Irish Studies, Charles University, 2006.

Sinclair, Hugh M. Camp and Society. London: Chapman and Hall, 1926.

Stephanides, Stephanos. "Octobriana". Leaves of Autumn: International Poetry. Ed. Gino Leineweber. Verlag Expeditionen, 2018. 109-110.

Stephanides, Stephanos and Stavros Karayianni, eds. Vernacular Worlds. Cosmopolitan Imagination. Leiden: Brill, 2015.

Ware, Timothy. The Orthodox Church. Harmondsworth: Penguin, 1997.

Yashin, Mehmet. "Someone Else's Father". Journal of Levantine Studies 4.2 (Winter 2014) 26 October 2018. https://levantine-journal.org/mehmet-yashin-poetry/

\section{Email Correspondence}

Michael, Olga. "Re: Straw Poll: Irish Studies”. Message to Paul Stewart. 16 October 2018. Email.

Stephanides, Stephanos. "Re: Straw Poll: Irish Studies”. Message to Paul Stewart. 8 October 2018. E-mail.

Received: 8 November $2018 \quad$ Revised version accepted: 15 February 2019

Paul Stewart is Professor of Literature at the University of Nicosia. He is the author of two books on Beckett - Sex and Aesthetics in Samuel Beckett's Works (Palgrave, 2011) and Zone of Evaporation: Samuel Beckett's Disjunctions (Rodopi, 2006) - and the series editor for "Samuel Beckett in Company", published by Ibidem Press.

stewartp@me.com 